Artikel Penelitian

\title{
Karakteristik Mi Kering Substitusi Tepung Terigu dengan Tepung Labu Kuning dan Tepung Ikan Tuna
}

\section{Dry Noodles Characteristics of Substitution Wheat Flour with Pumpkin and Tuna Flour}

Meda Canti ${ }^{*}$, Ivana Fransiska, Diana Lestari

Program Studi Teknologi Pangan, Fakultas Teknobiologi, Universitas Katolik Indonesia Atma Jaya, Jakarta

*Korespondensi dengan penulis (meda.canti@atmajaya.ac.id)

Artikel ini dikirim pada tanggal 18 Desember 2019 dan dinyatakan diterima tanggal 7 September 2020. Artikel ini juga dipublikasi secara online melalui https://ejournal2.undip.ac.id/index.php/jatp. Hak cipta dilindungi undang-undang. Dilarang diperbanyak untuk tujuan komersial.

Diproduksi oleh Indonesian Food Technologists $₫(C 2020$

\begin{abstract}
Abstrak
Mi kering merupakan produk yang digemari oleh masyarakat Indonesia. Hal ini menyebabkan penggunaan tepung terigu dan impor gandum meningkat. Oleh karena itu perlu adanya bahan untuk substitusi tepung terigu, yaitu dengan labu kuning dan ikan tuna. Tujuan dari penelitian ini untuk mensubstitusi sebagian tepung terigu dengan tepung labu kuning dan tepung ikan tuna terhadap sifat sensoris, fisik, dan kimia mi kering yang dihasilkan. Formulasi mi kering dibuat dengan rasio tepung terigu:tepung labu kuning: 100:0; 90:10; 80:20; 70:30; 60:40 dan tepung ikan tuna sebanyak $0-25 \%$, serta analisis mi kering meliputi sensori, fisik, kimia. Hasil penelitian menunjukkan bahwa mi kering yang masih dapat diterima panelis, yaitu mi kering dengan rasio 80:20 (tepung terigu:tepung labu kuning) dan penambahan tepung ikan tuna sampai dengan $20 \%$. Penambahan tepung ikan tuna sebesar $10-25 \%$ pada mi kering dapat meningkatkan daya serap air, tingkat pengembangan, cooking loss, dan menurunkan nilai kekerasan serta tensile strength. Mi kering dengan penambahan tepung ikan tuna hingga $20 \%$ mampu meningkatkan kandungan protein hingga 2,53 kali dibandingkan mi kering kontrol (tanpa penambahan tepung ikan tuna) dengan kadar protein sebesar $23,74 \% \mathrm{db}$. Kesimpulannya, penggunaan tepung ikan tuna sebagai sumber protein pada mi kering dapat dilakukan sampai dengan $20 \%$.
\end{abstract}

Kata kunci: mi kering, protein, tepung ikan tuna, tepung labu kuning.

\begin{abstract}
Dry noodles are a product that is favored by the most people in Indonesia. That causes the use of wheat flour and wheat imports to increase. Therefore it is necessary to have materials to substitute wheat flour, namely with pumpkin and tuna. The purpose of this study was to determine the partial substitution of wheat flour with pumpkin and tuna flour on the sensory, physical, and chemical properties of the dried noodles produced. The stages of the research included the making of pumpkin and tuna flour, dry noodles formulation with the ratio of wheat flour: pumpkin flour of 100:0, 90:10, 80:20, 70:30, 60:40, and tuna flour at the concentration of 0-25\%. The analysis of dried noodles was sensory, physical, chemical. The results showed that dry noodles were still acceptable to panelists, namely dry noodles with a ratio of 80:20 (wheat flour: pumpkin flour) and the addition of tuna flour up to $20 \%$. The addition of tuna flour by $10-25 \%$ to dry noodles could increase water absorption, expansion ratio, cooking loss, and reduce the value of hardness and tensile strength. Dry noodles with the addition of tuna flour up to $20 \%$ could increase protein content up to 2.53 times compared to dry noodles control (without tuna fish flour) with $23.74 \% \mathrm{db}$. As conclusion, the use of tuna flour as a protein source in dried noodles could be done up to $20 \%$.
\end{abstract}

Keywords: dried noodles, protein, tuna flour, pumpkin flour.

\section{Pendahuluan}

Mi merupakan salah satu makanan pokok tinggi karbohidrat yang disukai di Indonesia karena rasanya yang enak, murah, dan mudah didapatkan di Indonesia, dalam bentuk mi basah, mi instan, dan mi kering. Menurut SNI 8217:2015, mi kering dapat didefinisikan sebagai produk yang dibuat dari bahan baku utama tepung terigu dengan atau tanpa penambahan bahan pangan lain dan bahan tambahan pangan yang diizinkan melalui proses pencampuran, pengadukan, pencetakan lembaran (sheeting), pembuatan untaian (slitting), dengan atau tanpa pengukusan (steaming), pemotongan (cutting) berbentuk khas $\mathrm{mi}$, digoreng atau dikeringkan. Konsumsi mi kering terbilang cukup rendah di Indonesia sebesar $78 \mathrm{~g} / \mathrm{kapita} /$ tahun dibandingkan mi instan sebesar $4.972 \mathrm{~g} / \mathrm{kapita} / \mathrm{tahun}$ (Kementerian
Pertanian, 2018). Inovasi produk mi kering dapat dilakukan untuk menarik minat masyarakat, yaitu dengan menambahkan nilai gizi pada produk mi. Mi yang berbahan dasar tepung terigu dapat berdampak pada peningkatan impor gandum. Konsumsi nasional tepung terigu tahun 2018 sebesar 2,6 kg per kapita/tahun atau $0,051 \mathrm{~kg}$ per kapita/minggu, sedangkan nilai impor gandum di Indonesia tahun 2018 sebanyak 8.196 ton (Kementerian Pertanian, 2018). Oleh karena itu, pada formulasi mi perlu dilakukan substitusi tepung terigu dengan bahan pangan lain.

Labu kuning merupakan salah satu bahan pangan yang dapat diolah menggantikan tepung terigu. Produksi labu kuning di Indonesia mencapai 523.063 ton (Fauzi et al., 2017), dan konsumsi labu kuning sebesar 466.400 ton (Kementerian Pertanian, 2018). Labu kuning 
memiliki kandungan karbohidrat yang tinggi sebesar $81,45 \% d b$ (Quintana et al., 2018). Selain itu labu kuning memiliki kandungan karoten $(6,10 \mathrm{mg} / 100 \mathrm{~g})$, kandungan fenol total (159,69 mg GAE/L), dan aktivitas antioksidan (79,53 mg/L) (Dinu et al., 2016). Tepung labu mengandung jumlah yang tinggi kalsium (121,7 mg/100 $\mathrm{g})$, zat besi $(7,1 \mathrm{mg} / 100 \mathrm{~g})$, seng $(3,1 \mathrm{mg} / 100 \mathrm{~g})$, total serat pangan (23,8 \%) (Kundu et al., 2012). Tepung labu kuning dapat digunakan untuk substitusi sebagian tepung terigu meningkatkan serat pangan, kalsium, dan $\beta$-karoten dalam produk makanan berbasis tepung terigu yaitu mi kering. Akan tetapi, tepung labu kuning memiliki kandungan protein yang rendah sebesar 7,63 \% (Toan and Thuy, 2018), sehingga dapat menghasilkan produk pangan rendah protein. Untuk mengatasi hal tersebut, produk mi kering dapat ditambahkan bahan lain yang mengandung protein tinggi.

Ikan merupakan bahan pangan yang memiliki kandungan protein tinggi, salah satunya ikan tuna. Kadar protein ikan tuna sebesar $81,65 \%(\mathrm{db})$ dan setelah diolah menjadi tepung memiliki protein sebesar 90,66 \% (db) (Sahril and Lekahana, 2015). Ikan tuna juga mengandung omega 3 yang tinggi yaitu asam eikosapentanoat (EPA) sebesar $1,17 \%$ dan asam dokosaheksaenoat (DHA) sebesar 8,82 \% (Suseno, 2015). Ikan tuna merupakan produk kelautan Indonesia yang tingkat produksinya tinggi, yaitu mencapai 293.233 ton (KKP, 2018). Selain itu, ikan tuna juga banyak diekspor dari Indonesia sebesar 77.465,30 ton (BPS, 2015). Ikan tuna berpotensi sebagai penganekaragaman pangan lokal, salah satunya dengan pengolahan menjadi tepung. Sampai saat ini pemanfaatan tepung ikan tuna belum banyak digunakan dalam proses pembuatan mi padahal tepung ikan dapat dimanfaatkan untuk memperkaya kandungan protein pada mi sehingga meningkatkan nilai gizi dan fungsional mi kering. Tujuan penelitian ini adalah untuk mensubstitusi sebagian tepung terigu dengan tepung labu kuning dan tepung ikan tuna serta menganalisis karakteristik sensori, fisik dan kimia pada mi kering yang dihasilkan. Manfaat penelitian ini adalah memberikan informasi mengenai pemanfaatan tepung ikan tuna dan tepung labu kuning dalam proses pembuatan mi yang harapannya dapat memproduksi mi dengan nilai gizi yang tinggi.

\section{Materi dan Metode}

Materi

Penelitian ini dilakukan pada bulan September 2018 sampai dengan Agustus 2019 di Laboratorium Pengolahan Pangan, Fakultas Teknobiologi, Universitas Katolik Indonesia Atma Jaya. Bahan yang digunakan dalam penelitian ini, yaitu labu kuning yang diperoleh dari pasar moderen di kota Bekasi, tepung terigu dengan spesifikasi kandungan protein $11-13 \%$, ikan tuna yang diperoleh dari pasar tradisional Tangerang, sodium metabisulfit $\left(\mathrm{Na}_{2} \mathrm{~S}_{2} \mathrm{O}_{5}\right)$ (Aditya Birla Chemicals, Thailand.), garam alkali $\left(\mathrm{Na}_{2} \mathrm{CO}_{3}\right.$ dan $\mathrm{K}_{2} \mathrm{CO}_{3}$ ) (Merck, Germany), jeruk nipis, serta bahan kimia untuk analisis dengan kualitas P.A. (Pro Analysis).
Pembuatan Tepung Labu Kuning

Pembuatan tepung labu kuning dilakukan berdasarkan modifikasi dari metode Wahyono et al. (2018). Labu kuning (2,5 kg; dalam keadaan matang) dikupas dan dilakukan pembuangan kulit dan biji, lalu dicuci dengan air bersih. Labu dipotong tipis (2-4 $\mathrm{mm})$, kemudian direndam dengan larutan sodium metabisulfit. Modifikasi dilakukan dengan mengganti konsentrasi larutan metabisulfit $0,2 \%$ dan waktu perendaman selama 15 menit menjadi $0,25 \%$ selama 20 menit. Perendaman dalam larutan sodium metabisulfit berfungsi untuk mencegah reaksi pencoklatan enzimatis (melanin) dan non-enzimatis (melanoidin) sehingga warna tepung labu lebih cerah. Setelah itu, dilakukan pengeringan dengan oven pada suhu $60^{\circ} \mathrm{C}$ selama 42 jam. Selanjutnya, dilakukan penepungan dengan menggunakan food processor dan tepung diayak dengan saringan 60 mesh.

\section{Pembuatan Tepung Ikan Tuna}

Pembuatan tepung ikan tuna dilakukan mengikuti modifikasi dari metode Yulianti (2018a). Daging ikan tuna dicuci untuk menghilangkan kotoran, lendir, dan darah. Setelah itu, ikan direndam dalam larutan jeruk nipis $15 \%$ dengan rasio $1: 1(\mathrm{~b} / \mathrm{v})$ untuk mengurangi aroma amis. Modifikasi dilakukan dengan mengganti lama waktu perendaman selama 15 menit menjadi 30 menit. Selanjutnya, ikan dikukus dan dikeringkan. Modifikasi dilakukan dengan mengganti lama waktu pengukusan selama 15 menit menjadi 30 menit. Selain itu modifikasi juga dilakukan dengan mengganti suhu dan lama pengeringan yaitu $70^{\circ} \mathrm{C}$ selama 6 jam menjadi $50{ }^{\circ} \mathrm{C}$ selama 20 jam. Penepungan dilakukan menggunakan food processor dan diayak dengan saringan 60 mesh.

\section{Pembuatan Mi Kering}

Formulasi pada pembuatan mi kering dilakukan dengan 2 tahap. Formulasi tahap 1 menggunakan 2 tepung campuran yaitu tepung terigu dan tepung labu kuning, sedangkan formulasi tahap 2 menggunakan 3 tepung campuran yaitu tepung terigu, tepung labu kuning dan tepung ikan tuna. Formulasi tahap 1 rasio tepung terigu:tepung labu kuning yang digunakan sebesar (100:0), (90:10), (80:20), (70:30), dan (60:40). Mi kering dengan formulasi tahap 1, selanjutnya dilakukan analisis sensoris dengan uji kesukaan oleh 25 panelis semi terlatih dengan atribut warna, aroma, rasa, tekstur dan kesukaan keseluruhan (Larmond, 1973). Hasil analisis sensoris tersebut digunakan untuk menentukan rasio tepung terigu dan tepung labu kuning yang masih dapat diterima oleh panelis untuk formulasi mi kering tahap 2. Pada formulasi mi kering tahap 2, tepung ikan tuna yang digunakan sebesar $0,10,15,20$, dan $25 \%$. Semua bahan yang digunakan (tepung terigu, tepung labu kuning, tepung ikan tuna, garam alkali, air) dicampurkan dan dibentuk menjadi adonan. Penambahan garam alkali $\mathrm{Na}_{2} \mathrm{CO}_{3}: \mathrm{K}_{2} \mathrm{CO}_{3}$ (3:2) pada pembuatan mi kering sebesar $1 \%$, bertujuan untuk meningkatkan warna kuning pada mi yang dihasilkan, elastisitas dan fleksibilitas mi, kehalusan tekstur dan sifat 
Tabel 1. Uji kesukaan mi kering masak substitusi tepung terigu dengan tepung labu kuning

\begin{tabular}{lccccc}
\hline \multirow{2}{*}{$\begin{array}{l}\text { Rasio tepung terigu dan tepung } \\
\text { labu kuning }\end{array}$} & \multicolumn{5}{c}{ Uji kesukaan } \\
\cline { 2 - 6 } & Warna & Aroma & Rasa & Tekstur & Kesukaan keseluruhan \\
\hline $100: 0$ & $4,92 \pm 1,32^{\mathrm{a}}$ & $4,64 \pm 1,19^{\mathrm{a}}$ & $4,64 \pm 1,28^{\mathrm{a}}$ & $5,08 \pm 0,99^{\mathrm{a}}$ & $5,08 \pm 0,81^{\mathrm{a}}$ \\
$90: 10$ & $5,20 \pm 1,22^{\mathrm{a}}$ & $4,32 \pm 1,31^{\mathrm{a}}$ & $4,36 \pm 1,58^{\mathrm{a}}$ & $4,92 \pm 1,04^{\mathrm{a}}$ & $4,84 \pm 0,94^{\mathrm{ab}}$ \\
$80: 20$ & $4,68 \pm 1,18^{\mathrm{a}}$ & $4,32 \pm 1,11^{\mathrm{a}}$ & $4,36 \pm 1,35^{\mathrm{a}}$ & $4,64 \pm 0,86^{\mathrm{ab}}$ & $4,60 \pm 1,08^{\mathrm{ab}}$ \\
$70: 30$ & $4,52 \pm 1,23^{\mathrm{ab}}$ & $4,04 \pm 1,14^{\mathrm{a}}$ & $4,12 \pm 1,36^{\mathrm{ab}}$ & $4,20 \pm 1,08^{\mathrm{bc}}$ & $4,24 \pm 1,09^{\mathrm{bc}}$ \\
$60: 40$ & $3,84 \pm 1,65^{\mathrm{b}}$ & $4,00 \pm 1,47^{\mathrm{a}}$ & $3,40 \pm 1,32^{\mathrm{b}}$ & $3,96 \pm 1,144^{\mathrm{c}}$ & $3,76 \pm 1,39^{\mathrm{c}}$ \\
\hline
\end{tabular}

Huruf yang berbeda pada kolom yang sama menunjukkan perbedaan signifikan pada sampel $(a=0,05)$

Keterangan: 1 = sangat tidak suka; $2=$ tidak suka; $3=$ agak tidak suka; $4=$ netral; $5=$ agak suka; $6=$ suka; $7=$ sangat suka

Tabel 2. Uji kesukaan mi kering masak substitusi tepung terigu dengan tepung labu kuning dan tepung ikan tuna

\begin{tabular}{|c|c|c|c|c|c|c|c|}
\hline \multirow{2}{*}{$\begin{array}{l}\text { Rasio tepung } \\
\text { terigu:tepung } \\
\text { labu kuning }\end{array}$} & \multirow{2}{*}{$\begin{array}{c}\text { Tepung } \\
\text { ikan tuna } \\
(\%)\end{array}$} & \multicolumn{6}{|c|}{ Uji kesukaan } \\
\hline & & Warna & Aroma & Rasa & Tekstur & Aftertaste & $\begin{array}{c}\text { Kesukaan } \\
\text { keseluruhan }\end{array}$ \\
\hline \multirow[t]{5}{*}{$80: 20$} & 0 & $4,48 \pm 1,39^{a}$ & $5,32 \pm 1,11^{a}$ & $4,92 \pm 1,35^{a}$ & $5,20 \pm 1,56^{a}$ & $5,00 \pm 1,29 a$ & $5,40 \pm 1,56^{a}$ \\
\hline & 10 & $5,32 \pm 0,99^{b}$ & $5,12 \pm 1,09^{a}$ & $4,68 \pm 1,34^{a}$ & $4,76 \pm 1,09^{a b}$ & $4,88 \pm 1,24^{a}$ & $5,12 \pm 1,13^{a}$ \\
\hline & 15 & $5,36 \pm 0,99^{b}$ & $4,12 \pm 1,45^{b}$ & $4,56 \pm 1,26^{a}$ & $4,28 \pm 1,17^{b c}$ & $4,08 \pm 1,22^{b}$ & $4,76 \pm 1,09^{a b}$ \\
\hline & 20 & $5,72 \pm 0,7^{b}$ & $4,12 \pm 1,59^{b}$ & $4,48 \pm 1,33^{a}$ & $4,24 \pm 1,39 b c$ & $4,04 \pm 1,54^{b}$ & $4,24 \pm 1,56^{b}$ \\
\hline & 25 & $5,48 \pm 1,05^{b}$ & $3,56 \pm 1,39 b$ & $3,72 \pm 1,31^{b}$ & $3,68 \pm 1,38^{c}$ & $3,56 \pm 1,29 b$ & $3,52 \pm 1,32^{c}$ \\
\hline
\end{tabular}

Huruf yang berbeda pada kolom yang sama menunjukkan perbedaan signifikan pada sampel $(a=0,05)$

Keterangan: $1=$ sangat tidak suka; $2=$ tidak suka; $3=$ agak tidak suka; $4=$ netral; $5=$ agak suka; $6=$ suka; $7=$ sangat suka

kenyal pada mi (Karim and Sultan, 2015). Adonan yang terbentuk dibuat menjadi bulatan kecil, lalu digiling dengan noodle maker menjadi lembaran. Proses ini dilakukan sampai permukaan adonan halus. Lembaran adonan didiamkan selama 15 menit agar proses gelatinasi optimal. Selanjutnya, dilakukan penggilingan kembali dengan ketebalan $4 \mathrm{~mm}$. Adonan mi yang telah digiling didiamkan selama 30 menit, lalu dikukus pada suhu $100{ }^{\circ} \mathrm{C}$ selama 15 menit. Pengeringan dilakukan dengan oven selama 3 jam pada suhu $60^{\circ} \mathrm{C}$. Setelah itu, mi kering didinginkan pada suhu ruang selama 15 menit.

\section{Analisis Sifat Sensoris, Fisik dan Kimia Mi Kering}

Analisis sifat sensoris yaitu uji kesukaan oleh 25 panelis tidak terlatih (Larmond, 1973). Analisis sifat fisik meliputi daya serap air (Ko et al., 2015), daya pengembangan (Bhise et al., 2014), cooking loss (Ko et al., 2015), dan profil tekstur menggunakan texture analyzer (Agrosta, Prancis) (Ko et al., 2015). Analisis sifat kimia meliputi analisis kadar air, abu, dan protein sesuai prosedur AOAC (2002).

\section{Analisis Statistik}

Penelitian dilakukan sebanyak 2 kali ulangan perlakuan, setiap perlakuan dilakukan 3 kali ulangan analisis. Data yang diperoleh kemudian dilakukan uji statistik dengan analisis keragaman (ANOVA) dan uji beda nyata terkecil Duncan's Multiple Range Test (DMRT) dengan tingkat signifikasi 95\%. Data dianalisis menggunakan SPSS Versi 24.

\section{Hasil dan Pembahasan}

Analisis sensoris mi kering masak substitusi tepung terigu dengan tepung labu kuning

Berdasarkan Tabel 1, hasil uji kesukaan atribut warna, aroma, rasa, tekstur, dan secara keseluruhan mi kering masak substitusi tepung terigu dengan tepung labu kuning rasio 80:20 tidak berbeda nyata dengan mi kering masak substitusi tepung terigu dengan tepung labu kuning rasio 100:0 (kontrol). Mi kering masak substitusi tepung terigu dengan tepung labu kuning rasio 80:20 berwarna kuning, agak beraroma dan agak terasa labu kuning. Pada mi kering masak substitusi tepung terigu dengan tepung labu kuning rasio 60:40, kesukaan panelis memiliki nilai terendah pada atribut warna, rasa, dan tekstur yang tingkat kesukaannya berbeda nyata dengan mi kering masak kontrol. Mi kering masak substitusi tepung terigu dengan tepung labu kuning rasio 60:40 berwarna kuning tua, terasa labu kuning, dan tekstur agak kenyal. Kesukaan panelis terhadap atribut warna, rasa, tekstur, dan secara keseluruhan mi kering masak substitusi tepung terigu dengan tepung labu kuning rasio 70:30, tidak berbeda nyata dengan rasio $60: 40$. Berdasarkan hasil uji sensoris tersebut rasio tepung terigu dan tepung labu kuning yang digunakan untuk pembuatan mi kering untuk formulasi kedua yaitu 80:20. Hasil tersebut sesuai dengan penelitian Anam and Handajani (2010), bahwa mi kering yang disukai oleh panelis berdasarkan atribut warna, aroma, rasa, dan tekstur yaitu dengan kombinasi perlakuan substitusi tepung labu kuning sebesar $20 \%$ dan tanpa penambahan tepung angkak. Selain itu berdasarkan evaluasi sifat sensoris penambahan tepung labu kuning lebih tinggi dibandingkan dengan penelitian Park et al. (2015), melaporkan mi kering yang diterima panelis dengan penambahan tepung labu kuning sebesar $10 \%$.

\section{Analisis Sensoris Mi Kering Masak}

Hasil uji sensoris mi kering masak substitusi tepung terigu dengan tepung labu kuning dan tepung ikan tuna menunjukkan mi yang masih dapat diterima oleh panelis yaitu mi kering dengan penambahan tepung ikan tuna hingga 20\% (Tabel 2). Kesukaan secara keseluruhan mi kering masak substitusi tepung terigu dengan tepung labu kuning dan penambahan tepung ikan tuna $20 \%$ tidak berbeda nyata dengan mi kering dengan penambahan tepung ikan tuna $15 \%$; penambahan tepung ikan tuna $15 \%$ tersebut juga tidak 
Tabel 3. Hasil analisis fisik mi kering substitusi tepung terigu dengan tepung labu kuning dan tepung ikan tuna

\begin{tabular}{lcccccc}
\hline $\begin{array}{l}\text { Tepung } \\
\text { terigu:tepung } \\
\text { labu kuning }\end{array}$ & $\begin{array}{c}\text { Tepung } \\
\text { ikan tuna } \\
(\%)\end{array}$ & $\begin{array}{c}\text { Daya serap } \\
\text { air (\%) }\end{array}$ & $\begin{array}{c}\text { Daya } \\
\text { pengembangan } \\
(\%)\end{array}$ & $\begin{array}{c}\text { Cooking loss } \\
(\%)\end{array}$ & Kekerasan (gf) & Tensile (gf) \\
\hline $80: 20$ & 0 & $144,34 \pm 4,84^{\mathrm{a}}$ & $16,61 \pm 0,39^{\mathrm{a}}$ & $11,41 \pm 0,48^{\mathrm{a}}$ & $7.323,00 \pm 135,43^{\mathrm{a}}$ & $53,67 \pm 2,94^{\mathrm{a}}$ \\
& 10 & $155,23 \pm 3,07^{\mathrm{b}}$ & $17,77 \pm 0,46^{\mathrm{b}}$ & $11,76 \pm 0,36^{\mathrm{a}}$ & $7.054,50 \pm 106,78^{\mathrm{b}}$ & $44,17 \pm 2,64^{\mathrm{b}}$ \\
& 15 & $166,90 \pm 2,54^{\mathrm{c}}$ & $20,19 \pm 0,31^{\mathrm{c}}$ & $12,58 \pm 0,94^{\mathrm{b}}$ & $6.923,00 \pm 49,64^{\mathrm{b}}$ & $34,83 \pm 2,79^{\mathrm{c}}$ \\
& 20 & $168,86 \pm 2,82^{\mathrm{c}}$ & $21,82 \pm 0,35^{\mathrm{d}}$ & $14,33 \pm 0,51^{\mathrm{c}}$ & $6.686,50 \pm 127,4^{\mathrm{c}}$ & $25,83 \pm 2,32^{\mathrm{d}}$ \\
& 25 & $173,12 \pm 3,43^{\mathrm{d}}$ & $22,37 \pm 0,82^{\mathrm{d}}$ & $17,04 \pm 0,48^{\mathrm{d}}$ & $6.312,33 \pm 149,63^{\mathrm{d}}$ & $18,17 \pm 0,98^{\mathrm{e}}$ \\
\hline
\end{tabular}

Huruf yang berbeda pada kolom yang sama menunjukkan perbedaan signifikan pada sampel $(\alpha=0,05)$

Tabel 4. Hasil analisis kimia mi kering substitusi tepung terigu dengan tepung labu kuning dan tepung ikan tuna

\begin{tabular}{lcccc}
\hline $\begin{array}{l}\text { Tepung terigu:tepung } \\
\text { labu kuning }\end{array}$ & $\begin{array}{c}\text { Tepung ikan tuna } \\
(\%)\end{array}$ & $\begin{array}{c}\text { Kadar Air } \\
(\% w b)\end{array}$ & $\begin{array}{c}\text { Kadar Abu } \\
(\% d b)\end{array}$ & $\begin{array}{c}\text { Kadar Protein } \\
(\% d b)\end{array}$ \\
\hline $80: 20$ & 0 & $7,40 \pm 0,32^{\mathrm{a}}$ & $1,92 \pm 0,07^{\mathrm{a}}$ & $9,36 \pm 0,17^{\mathrm{a}}$ \\
& 10 & $7,67 \pm 0,13^{\mathrm{b}}$ & $2,13 \pm 0,06^{\mathrm{b}}$ & $17,43 \pm 0,16^{\mathrm{b}}$ \\
& 15 & $7,94 \pm 0,24^{\mathrm{c}}$ & $2,27 \pm 0,05^{\mathrm{c}}$ & $20,80 \pm 0,32^{\mathrm{c}}$ \\
& 20 & $8,10 \pm 0,13^{\mathrm{c}}$ & $2,41 \pm 0,04^{\mathrm{d}}$ & $23,74 \pm 0,34^{\mathrm{d}}$ \\
\hline
\end{tabular}

Huruf yang berbeda pada kolom yang sama menunjukkan perbedaan signifikan pada sampel $(a=0,05)$

berbeda nyata dengan kesukaan keseluruhan mi kering kontrol (tanpa penambahan tepung ikan tuna). Penambahan tepung ikan tuna $20 \%$ pada mi kering masak tidak mempengaruhi kesukaan panelis pada atribut warna dan rasa. Mi kering masak dengan penambahan tepung ikan tuna 20\% menghasilkan warna kuning dan agak terasa ikan tuna. Kesukaan panelis secara keseluruhan terhadap mi kering masak dengan penambahan tepung ikan tuna $25 \%$ berbeda nyata dengan mi kering kontrol. Atribut rasa mi kering masak dengan penambahan tepung ikan tuna sebesar $25 \%$ menunjukkan hasil yang rendah yaitu terasa ikan tuna. Hasil penelitian ini sesuai dengan Yulianti (2018b), menyatakan mi kering dengan substitusi tepung ubi jalar dan penambahan tepung ikan cakalang sebesar $20 \%$ disukai oleh panelis baik dari atribut warna, aroma, rasa, maupun tekstur. Penambahan tepung ikan lele sebesar $20 \%$ pada mi kering mocaf-tepung terigu disukai dalam atribut warna, tekstur, aroma, dan rasa (Agustia et al., 2019). Menurut Debbarma et al. (2017), mi kering dengan penambahan daging ikan patin sebesar $20 \%$ diterima panelis dalam atribut warna, kenampakan, aroma, rasa, tekstur, dan kesukaan keseluruhan.

\section{Analisis Fisik Mi Kering}

Kualitas mi masak ditentukan oleh parameter sebagai berikut memiliki daya serap air yang tinggi, cooking loss rendah dan memiliki tekstur yang baik yaitu mi padat dan keras serta nilai kelengketan rendah (Bruneel et al., 2010). Nilai daya serap air pada mi kering substitusi tepung terigu dengan tepung labu kuning dan penambahan tepung ikan tuna sebesar 10-25\% menunjukkan perbedaan nyata dengan mi kering kontrol (tanpa penambahan ikan tuna) (Tabel 3). Semakin tinggi penambahan tepung ikan tuna pada mi kering, maka semakin tinggi daya serap air. Hal ini disebabkan tepung ikan tuna dan tepung labu kuning masing-masing memiliki Water Holding Capacity (WHC) sebesar 299,01 dan $200,62 \%$, yang lebih tinggi dibandingkan tepung terigu (yaitu sebesar 93,30\%) (data tidak ditampilkan). Daya serap air dipengaruhi oleh matriks gluten dan ikatan hidrogen pada mi. Semakin rendah matriks gluten dan semakin lemah ikatan hidrogen maka daya serap air pada mi akan semakin tinggi (Ahmed et al., 2015). Berbeda dengan penelitian Desai et al. (2018), melaporkan adanya penurunan daya serap air pasta dengan semakin tinggi penambahan tepung ikan codling merah (Pseudophycis bachus). Hal ini karena selama pembentukan pasta terjadi kompetisi antara tepung ikan dengan pati, sehingga menyebabkan penurunan daya serap air dan pengembangan pasta.

$$
\text { Daya pengembangan }
$$

menunjukkan pengembangan volume mi yang dapat terjadi jika mi kering dimasak. Semakin tinggi penambahan tepung ikan tuna, maka daya pengembangan mi kering masak dinilai semakin tinggi. Nilai daya pengembangan pada mi kering mi kering substitusi tepung terigu dengan tepung labu kuning dan penambahan tepung ikan tuna sebesar $10-25 \%$ menunjukkan perbedaan nyata dengan mi kontrol (Tabel 3). Daya pengembangan mi kering masak dipengaruhi WHC tepung yang digunakan pada pembuatan mi. WHC tepung ikan tuna lebih tinggi dibandingkan WHC tepung terigu dan tepung labu kuning, sehingga akan meningkatkan volume mi ketika dimasak. Tingkat pengembangan mi mempengaruhi kualitas dan tekstur mi masak. Semakin tinggi daya pengembangan mi maka tekstur mi yang dihasilkan akan semakin lunak dan lengket, sedangkan semakin rendah daya pengembangan mi maka akan menghasilkan mi dengan tekstur yang keras. Oleh karena itu dibutuhkan nilai optimal tingkat pengembangan mi (Ahmed et al., 2015).

Cooking loss merupakan kehilangan padatan mi selama pemasakan dan merupakan parameter mutu yang berkaitan dengan kualitas mi setelah dimasak. Cooking loss pada mi kering dengan penambahan tepung ikan tuna $10 \%$ menunjukkan perbedaan tidak nyata dengan mi kontrol, tetapi berbeda nyata dengan mi kering dengan penambahan tepung ikan tuna sebesar 15-25\% (Tabel 3). Semakin tinggi penambahan tepung ikan tuna dapat meningkatkan cooking loss mi kering. Hasil ini sesuai yang dilaporkan oleh Desai et al. (2018), semakin tinggi penambahan tepung ikan codling 
merah pada pasta masak maka cooking loss juga semakin tinggi. Cooking loss dipengaruhi oleh daya serap air mi, semakin tinggi daya serap air mi maka semakin tinggi cooking loss. Hal ini dikarenakan partikel mi semakin mengembang dan semakin banyak karbohidrat yang larut ke dalam air perebusan mi (Bruneel et al., 2010). Cooking loss juga dapat terjadi akibat terlepasnya molekul pati linier rantai pendek pada untaian mi ke dalam air saat proses perebusan. Penambahan tepung ikan tuna yang tidak memiliki kandungan gluten seperti tepung terigu akan mengurangi kandungan gluten pada mi kering yang dihasilkan. Gluten memiliki fungsi dalam membentuk struktur tiga dimensi yang menghalangi keluarnya granula pati selama pemasakan (Ahmed et al., 2015). Cooking loss yang tinggi mengindikasikan tekstur mi yang dimasak memiliki permukaan yang lengket dan tidak diinginkan (Shiau and Chang, 2013).

Kekerasan merupakan daya tahan bahan untuk patah akibat gaya tekan yang diberikan. Nilai kekerasan mi kering substitusi tepung terigu dengan tepung labu kuning dan penambahan tepung ikan tuna sebesar 10$25 \%$ menunjukkan perbedaan nyata dengan mi kering kontrol (Tabel 3). Semakin besar gaya tekan yang dibutuhkan maka kekerasan produk juga semakin tinggi. Penambahan tepung ikan tuna dapat menurunkan kekerasan mi kering masak. Penurunan kekerasan dengan semakin tinggi penambahan daging ikan juga dilaporkan oleh Nawaz et al. (2020). Penurunan kekerasan pada mi kering masak dapat disebabkan oleh nilai cooking loss dan kemampuan penyerapan air. Tepung yang memiliki WHC tinggi menyebabkan kandungan air semakin meningkat sehingga kekerasan mi kering masak dapat menurun (Sukri et al., 2016). Cooking loss yang tinggi juga menyebabkan banyaknya molekul pati yang hilang sehingga mi kering masak menjadi kurang padat. Tekstur pada mie dipengaruhi oleh kadar pati. Tepung terigu memiliki kadar pati yang lebih tinggi dibandingkan dengan tepung labu kuning dan ikan tuna. Kadar pati tepung terigu dan tepung labu kuning berturut-turut sebagai berikut $80,65 \% \mathrm{db}$ (Lin et al., 2019); 48,30 \% (Saeleaw and Schleining, 2011). Kadar karbohidrat ikan tuna sebesar 12,51\% (Suseno, 2015). Kandungan pati yang tinggi menyebabkan tekstur mi lebih padat dan keras. Kandungan pati yang berperan dalam proses retrogradasi semakin berkurang sehingga kekerasan menurun (Yulianti, 2018a).

Tensile merupakan kemampuan bahan untuk menahan gaya tarikan yang diberikan pada besaran tertentu hingga putus (Sukri et al., 2016). Nilai tensile mi kering substitusi tepung terigu dengan tepung labu kuning dan penambahan tepung ikan tuna sebesar 10$25 \%$ menunjukkan perbedaan nyata dengan mi kering kontrol (Tabel 3). Penambahan tepung ikan tuna juga akan menurunkan nilai tensile. Penurunan nilai tensile ini menunjukkan mutu mi kering masak yang kurang baik, yaitu mudah putus. Hal ini disebabkan penambahan tepung ikan tuna menyebabkan semakin sedikit kandungan gluten dalam mi kering. Kandungan gluten ini berfungsi dalam membentuk ikatan kuat antara granula pati yang menyebabkan ketahanan terhadap tarikan
(Ahmed et al., 2016). Nilai tensile juga dipengaruhi oleh kemampuan pengembangan. Tepung atau pati yang memiliki kemampuan pengembangan yang tinggi akan memiliki nilai tensile yang semakin kecil (Tan et al., 2009). Nilai tensile mi kering pada penelitian ini $(18,17$ gf) lebih tinggi dibandingkan mi kering substitusi mocaf dengan penambahan $25 \%$ ikan bandeng (Kencana et al., 2018).

\section{Analisis Kimia Mi Kering}

Kadar air mi kering dengan penambahan tepung ikan hingga $20 \%$ telah sesuai dengan syarat mutu SNI 8217:2015, yaitu maksimal $13 \%$ (Tabel 4) (SNI, 2015). Penambahan tepung ikan tuna meningkatkan kadar air mi kering yang dihasilkan. Hasil ini serupa dengan penelitian Nawaz et al. (2020), kadar air mi instan (5,95$7,45 \%)$ semakin meningkat dengan semakin tinggi penambahan daging ikan sebesar $10-30 \%$. Kadar air mi kering substitusi tepung terigu dengan tepung labu kuning dan penambahan tepung ikan tuna sebesar 10$20 \%$ menunjukkan perbedaan nyata dengan mi kering kontrol (tanpa penambahan tepung ikan tuna). Hal ini dapat disebabkan oleh WHC tepung ikan tuna yang tinggi sehingga air yang ditambahkan dalam adonan mi kering semakin banyak.

Kadar abu mi kering hingga penambahan tepung ikan tuna hingga $20 \%$ sesuai dengan syarat mutu SNI 8217:2015, yaitu maksimal $3 \%$ (Tabel 4) (SNI, 2015). Kadar abu mi kering substitusi tepung terigu dengan tepung labu kuning dan penambahan tepung ikan tuna sebesar $10-20 \%$ menunjukkan perbedaan nyata dengan mi kering kontrol. Kadar abu mi kering dengan penambahan tepung ikan tuna akan meningkat seiring dengan semakin tinggi konsentrasi tepung ikan tuna. Hal ini disebabkan penambahan tepung ikan tuna yang memiliki kadar abu $(4,88 \% \mathrm{db})$ lebih tinggi dibandingkan tepung terigu $(0,53 \% \mathrm{db})$ dapat meningkatkan kadar abu mi kering. Menurut Desai et al. (2018), kadar abu pasta mentah dan masak meningkat dengan semakin tinggi penambahan tepung ikan codling merah. Oleh karena tepung ikan yang digunakan memiliki kandungan abu yang tinggi.

Kadar protein pada mi kering dengan penambahan tepung ikan tuna hingga $20 \%$ telah sesuai dengan syarat mutu SNI 8217:2015, yaitu minimal $10 \%$ (Tabel 4) (SNI, 2015). Kadar protein mi kontrol sebesar $9,36 \%(\mathrm{db})$ tidak memenuhi syarat mutu SNI mi kering. Kadar protein mi kering substitusi tepung terigu dengan tepung labu kuning dan penambahan tepung ikan tuna sebesar 10-20\% menunjukkan perbedaan nyata dengan mi kering kontrol. Protein tepung ikan tuna $(85,13 \% \mathrm{db})$ ini juga lebih tinggi dibandingkan tepung terigu dan tepung labu kuning (masing-masing 11,77 \% db; 3,96 \% $\mathrm{db}$ ) sehingga mampu meningkatkan kadar protein mi kering. Mi kering dengan penambahan tepung ikan tuna $20 \%$ memiliki kadar protein sebesar $23,74 \% \mathrm{db}$, yang mampu meningkatkan kandungan protein hingga 2,53 kali lipat dibandingkan protein mi kering kontrol. Kadar protein mi kering dengan penambahan tepung ikan tuna sebesar $10-20 \% \quad(17,43-23,74 \%)$ lebih tinggi dibandingkan mi kering dengan penambahan tepung 
ikan cakalang sebesar 20-50 \% (11,09-11,93\%); daging ikan patin sebesar $20 \%(7,66 \%)$; daging ikan kembung sebesar $25 \%$ pada mi kering mocaf (13,80\%); daging ikan nila sebesar $25 \%$ pada mi kering mocaf (13,04\%); daging ikan bandeng sebesar $25 \%$ pada mi kering mocaf (15,35\%); daging ikan sebesar $40 \%$ pada mi kering rumput laut $(17,26 \%)$; konsentrat protein ikan nila sebesar $10-20 \%$ pada pasta basah $(12,48-15,34 \%)$ (Debbarma et al., 2017; Goes et al., 2016; Kencana et al., 2018; Murniyati et al., 2010; Yulianti, 2018b).

\section{Kesimpulan}

Mi kering substitusi tepung terigu dengan tepung labu kuning dan tepung ikan tuna yang disukai oleh panelis yaitu rasio 80:20 (tepung terigu:tepung labu kuning) dan penambahan tepung ikan tuna sampai dengan $20 \%$. Penambahan tepung ikan tuna sebesar 10-25\% pada mi kering akan mempengaruhi sifat fisik mi kering seperti meningkatkan daya serap air, daya pengembangan, dan cooking loss, serta menurunkan nilai kekerasan dan tensile. Selain itu, penambahan tepung ikan tuna juga mempengaruhi sifat kimia mi kering seperti meningkatkan kadar air, abu, dan protein.

\section{Ucapan Terima Kasih}

Terimakasih diberikan kepada Lembaga Penelitian dan Pengabdian Masyarakat (LPPM) Universitas Katolik Indonesia Atma Jaya, melalui program hibah penelitian Fakultas Teknobiologi tahun 2018.

\section{Daftar Pustaka}

Agustia, F.C., Soebardjo, Y.P., Ramadhan, G.R. 2019. Development of mocaf-wheat noodle product with the addition of catfish and egg-white flours as an alternative for high-animal-protein noodles. Jurnal Aplikasi Teknologi Pangan 8(2):47-51. DOI: 10.17728/jatp.2714

Ahmed, I,. Qazi, I.M., Jamal, S. 2015. Quality evaluation of noodles prepared from blending of broken rice and wheat flour. Starch Journal 67:905-912. DOI: 10.1002/star.201500037

Ahmed, I., Qazi, I.M., Li, Z., Ullah, J. 2016. Rice noodles: materials, processing and quality evaluation. Proceedings of The Pakistan Academy of Sciences: B. Life and Enviromental Sciences 53(3):215-238.

Anam, C., Handajani, S. 2010. Mi kering waluh (Cucurbita moschata) dengan antioksidan dan pewarna alami. Caraka Tani: Journal of Sustainable Agriculture 25(1):72-78. DOI: 10.20961/carakatani.v25i1.15744.

AOAC (Association of Official Analytical Chemists). 2000. Official Methods of Analysis of AOAC (Ed. 17). AOAC International. Gaithersburg, US.

AOAC. (Association of Official Analytical Chemists). 2002. Official Methods of Analysis. Protein (crude) in animal feed, forage (plant tissue), grain, and oilseeds. AOAC International. Virginia, US.

Bhise, S., Kaur, A., Aggarwal, P. 2014. Development of protein enriched noodles using texturized defatted meal from sunflower, flaxseed and soybean. Journal of Food Science and Technology 52(9):5882-5889. DOI:10.1007/s13197-014-16301

BPS (Badan Pusat Statistik). 2015. Badan pusat statistik: ekspor ikan tongkol/tuna menurut negara tujuan utama 20022015.https://www.bps.go.id/statictable/2014/09/08 /1019/ekspor-ikan-tongkol-tuna-menurut-negaratujuan-utama-2002-2015.html (Diakses tanggal 9 Desember 2019).

Bruneel, C., Pareyt, B., Brijs, K., Delcour, J. A. 2010. The impact of the protein network on the pasting and cooking properties of dry pasta products. Journal of Food Chemistry 120:371-378. DOI:10.1016/j.foodchem.2009.09.069.

Debbarma, J., Viji, P., Rao, B.M., Prasad, M.M. 2017. Nutritional and physical characteristics of noodles incorporated with green seaweed (Ulva reticulata) and fish (Pangasianodon hypophthalmus) mince. Indian Journal of Fisheries 64(2):90-95. DOI:10.21077/ijf.2017.64.2.58918-14.

Desai, A., Brennan, M.A., Brennan, C.S. 2018. The effect of semolina replacement with protein powder from fish (Pseudophycis bachus) on the physicochemical characteristics of pasta. LWTFood Science and Technology 89:52-57. DOI: 10.1016/j.Iwt.2017.10.023.

Dinu, M., Soare, R., Hoza, G., Becherescu, A.D. 2016. Biochemical composition of some local pumpkin population. Journal of Agriculture and Agricultural Science Procedia 10: 185-191. DOI:10.1016/j.aaspro.2016.09.051.

Fauzi, M., Kuliahsari, D.E., Diniyah, N., Rusdianto, A.S. 2017. Penggunaan vitamin $C$ dan suhu pengeringan pada pembuatan chip (irisan kering) labu kuning LA3 (Cucurbita moschata). Jurnal Penelitian Pascapanen Pertanian 14(2):108-115. DOI:10.21082/jpasca.v14n2.2017.108-115

Goes, E.S.D.R., De-Souza, M.L.R. Michka, J.M.G., Kimura, K.S., De-Lara, J.A.F., Delbem, A.C.B., Gasparino, E. 2016. Fresh pasta enrichment with protein concentrate of tilapia: nutritional and sensory characteristics. Journal of Food Sience and Technology 36(1):76-82. DOI:10.1590/1678457X.0020.

Karim, R., Sultan, M.T. 2015. Yellow Alkaline Noodles: Processing Technology and Quality Improvement. Springer International Publishing. Switzerland.

Kencana, I.P., Darmanto, Y.S., Sumardianto. Pengaruh penambahan lumatan daging ikan kembung (Rastrelliger sp.), nila (Oreochromis niloticus), dan bandeng (Chanos chanos forsk) terhadap karakteristik mie kering tersubstitusi mocaf. Jurnal IImu Pangan dan Hasil Pertanian 2(1):53-62). DOI:10.26877/jiphp.v2i1.2300.

KKP (Kementerian Kelautan dan Perikanan). 2018. Refleksi 2018 \& Outlook 2019.https://kkp.go.id/ancomponent/media/upload-gambarpendukung/kkp/DATA\%20KKP/Bahan\%20RO\%2 
OKKP\%202018\%20(final).pdf (Diakses tanggal 9 Desember 2019)

Kementerian Pertanian. 2018. Statistik Konsumsi Pangan Tahun 2018. http://epublikasi.setjen.pertanian.go.id/download/f ile/450-statistik-konsumsi-pangan-tahun-2018 (Diakses tanggal 9 Desember 2019).

Ko, J.A, Kim, H.S, Baek, H.H, Park, H.J. 2015. Effects of hydroxypropyl methylcellulose and temperature of dough water on the rice noodle quality. Food Science and Technology Research 21(1):129-135. DOI: 10.3136/fstr.21.129.

Kundu, H., Grewal, R.B., Goyal, A., Upadhyay, N., Prakash, S. 2014. Effect of incorporation of pumpkin (Cucurbita moshchata) powder and guar gum on the reological properties of wheat flour. Journal Food Science Technology 51(10):26002607. DOI: 10.1007/s13197-012-0777-x.

Larmond, E. 1973. Methods for Sensory Evaluation of Food. Canada Department of Agriculture, Ottawa.

Lin, J., Gu, Y., Bian, K. 2019. Bulk and surface chemical composition of wheat flour particles of different sizes. Journal of Chemistry 2019:1-11. DOI: $10.1155 / 2019 / 5101684$.

Murniyati, Subaryono, Hermana, I. 2010. Pengolahan mie yang difortifikasi dengan ikan dan rumput laut sebagai sumber protein, serat kasar, dan iodium. Jurnal Pascapanen dan Bioteknologi Kelautan dan Perikanan 5(1):65-76. DOI: 10.15578/jpbkp.v5i1.427.

Nawaz, A., Li, E., Khalifa, I., Irshad, S., Walayat, N., Mohammed, H.H.H., Zhang, Z., Ahmed, S., Simirgiotis, M.J. 2020. Evaluation of fish meat noodles: physical property, dough rheology, chemistry and water distribution properties. International Journal of Food Science and Technology:1-9. DOI:10.1111/ijfs.14761.

Park, J.H., Choi, J.E., Lee, J.H. 2015. Selected physicochemical and consumer preference characteristics of noodles incorporated with sweet pumpkin powder. Journal of the Korean Society of Food Science and Nutrition 44(2):291-295. DOI: 10.3746/jkfn.2015.44.2.291.

Quintana, S.E., Marsiglia, R.M., Machacon, D., Torregroza, E., Garcia-Zapateiro, L.A. 2018. Chemical composition and physicochemical properties of squash (Cucurbita moschata) cultivated in Bolivar department (Colombia). Journal of Contemporary Engineering Sciences 11(21):1003-1012. DOI: 10.12988/ces.2018.8384.

Saeleaw, M., Schleining, G. 2011. Composition, physicochemical and morphological characterization of pumpkin flour. Proceedings the $11^{\text {th }}$ International Congress on Engineering and Food. Athens, Greece.

Sahril, D.F., Lekahena, V.N.J. 2015. Pengaruh konsentrasi asam asetat terhadap karakteristik fisikokimia tepung ikan dari daging merah ikan tuna. Jurnal Ilmiah Agribisnis dan Perikanan 8(1):69-76. DOI:10.29239/j.agrikan.8.1.69-76.

Shiau, Sy-Yu, Chang, Yung-Ho. 2013. Instrumental textural and rheological properties of raw, dried, and cooked noodles with transglutaminase. Internasional Journal of Food Properties 16(7):1429-1441.

DOI:10.1080/10942912.2011.593280.

SNI (Standar Nasional Indonesia) 8217-2015 Mi Kering. 2015. Badan Standarisasi Nasional. Jakarta. https://edoc.pub/24323sni-8217-2015-pdffree.html (Diakses 10 Desember 2019).

Suseno, S. H. 2015. Proximate, fatty acid, amino acid and mineral composition of Tuna (Thunus sp.) byproduct from West Sumatra Province, Indonesia. Pakistan Journal of Nutrition 14(1):62-66. DOI:10.3923/pjn.2015.62.66.

Sukri, N., Kusnandar, F., Purnomo, E.H., Risfaher. 2016. Aplikasi tepung walur (Amorphophallus campanulatus var. sylvetris) dalam pembuatan mie dan cookies. Jurnal Penelitian Pangan 1(1):51-59. DOI:10.24198/jp2.2016.vol1.1.09

Tan, H., Li., Z., Tan, B. 2009. Starch noodles: history, classification, materials, processing, structure, nutrition, quality evaluating and improving. Journal of Research International 42:551-576. DOI: 10.1016/j.foodres.2009.02.015.

Toan, N.V., Thuy, N.T.T. 2018. Production of high-quality flour and the made biscuits from pumpkin. International Journal of Food Science and Nutrition 3(5):157-166.

Wahyono, A., Kurniawati, E., Kasutjianingati, Park, K., Kang, W. 2018. Optimasi proses pembuatan tepung labu kuning menggunakan response surface methodology untuk meningkatkan aktivitas antioksidannya. Jurnal Teknologi dan Industri Pangan 29(1):29-38. DOI: 10.6066/jtip.2018.29.1.29.

Yulianti. 2018a. Penambahan tepung ikan cakalang sebagai sumber protein pada pembuatan bubur talas instan. Jurnal Galung Tropika 7(3):169-174. DOI:10.31850/jgt.v7i3.394.

Yulianti. 2018b. Pengaruh penambahan tepung ikan cakalang pada mie kering yang bersubtitusi tepung ubi jalar. Gorontalo Agriculture Technology Journal 1(2):8-15. DOI:10.32662/gatj.v1i2.418. 